\title{
APS in Brazil
}

I n New York, 1990, when I was about to come back to Brazil, just after finishing my fellowship in rheumatology, having been mentored by Professors Michael D. Lockshin and Azzudin E. Gharavi (so missed Aziz! He loved Brazil and made a lot of friends here), I was requested by the latter to help spread in my country, and if possible beyond its borders. The recent acquired knowledge about the antiphospholipid antibody syndrome (APS). The mission I had been delegated to, besides giving lectures to rheumatologists and other specialists, included publishing articles in the national medical journals and spreading the Brazilian experience abroad. When I was back here, I soon met two outstanding experts devoted to APS studies: Mittermayer Barreto Santiago from Bahia and Henrique Luiz Staub from Rio Grande do Sul. Both had just arrived from London, where they had been mentored by Professor Graham Hughes. By the time, they were working at USP and HSE-SP, respectively. Besides these institutions, other places started showing interest in the diagnosis and treatment of the APS, and also in carrying out research projects on it. Right afterwards, we could witness the standardization of the clinical tests for APS diagnosis and its implementation in the routine diagnosis labs.

It has been deeply rewarding to contribute enhancing the knowledge on APS in our own environment. Having witnessed the reports on retrospective cases by our most experienced colleagues as well as research projects on this matter, I can say that Professor Gharavi's request has already been granted. Even more gratifying is remaining on the front of practical rheumatology in good health, together with all the other professionals interested in this topic, and see that we do make a difference in people's lives with primary/isolated, or associated APS. However,
I still think that we have a lot to learn and to achieve with APS - a rheumatologic disease that has a great impact on internal medicine. It must be acknowledged by everyone and have diagnostic investigations carried out only by rheumatologists. We should even go beyond the borders of rheumatology, encouraging our basic science colleagues to contribute with multidisciplinary projects on APS. We hope to see the results of these projects proliferating so that in 2013, when the APS International Congress will be held in Rio de Janeiro, we could see new results being presented by the latest generation of Brazilian physicians.

This RBR issue presents the studies results performed at two of the most important centers of Brazilian rheumatology: FMUSP and UNIFESP. The study by Jozélio Freire de Carvalho and Maria Teresa Correia Caleiro $^{1}$ discusses the relation between lipoprotein(a) levels, found to be higher in individuals with APS than in the general population, with clinical and demographic features of 46 individuals with primary APS, $43 \%$ of whom presented increased lipoprotein(a) levels. No significant associations between lipoprotein(a) levels and APS characteristics were found. Anyway, it is important to identify the factors correlated with specific clinical manifestations and prognostic markers for APS. We are aware of the importance of controlling systemic arterial hypertension, which is related to APS arterial events, as well as homocysteine levels, which can be elevated in APS population increasing the thrombosis risk, independently., ${ }^{2,3}$

The study carried out by the staff of Professor Edmundo Vasconcelos Hospital, ${ }^{4}$ mentored by Alexandre Wagner Silva de Souza, demonstrates the clinical manifestations in a retrospective study including 106 individuals with antiphospholipid antibodies. It would be interesting 
to know the prospective follow-up of this cohort, and especially learn how those individuals with any type of antiphospholipid antibody persistently detected without a previous report of a thrombotic event or miscarriage will evolve. How will the women with obstetric events treated with different therapeutic modalities evolve? What is the predictive value of the various types of antibodies (including anti-beta 2 glycoprotein I) as well as the clinical features not included in the classification criterion (Raynaud's phenomenon, livedo, migraine, tinnitus, etc.) and different evolutionary forms?

In short, we have really advanced in the studies of such an important disease, unidentified until 1986, but there is still a lot to learn about it.

Roger A. Levy

Assistant Professor in Rheumatology at UERJ, scientific consultant at DASA and support from Federico Foundation

\section{REFERENCES}

1. Jozélio FC, Maria Teresa CC, Lipoproteína(a) na síndrome antifosfolípide primária. Rev Bras Reumatol 2009;49(3):246-253.

2. Souza AW, Silva NP, Carvalho JF, D'Almeida V, Noguti MA, Sato EI. Impact of hypertension and hyperhomocysteinemia on arterial thrombosis in primary antiphospholipid syndrome. Lupus 2007;16(10):782-7.
3. Martínez-Berriotxoa A, Ruiz-Irastorza G, Egurbide MV, Rueda M, Aguirre C. Homocysteine, antiphospholipid antibodies and risk of thrombosis in patients with systemic lupus erythematosus. Lupus 2004;13(12):927-33.

4. Alexandre Wagner SS, Paula GP, Daniela PD, Andreia LG, Augusta MR, Felipe MT et al. Avaliação da pesquisa de anticorpos antifosfolipídios para o diagnóstico da síndrome antifosfolípide. Rev Bras Reumatol 2009;49(3):236-245. 